\title{
Nitrogen and phosphorus resorption in a neotropical rain forest of a nutrient-rich soil
}

José Luis Martínez-Sánchez

Department of Biological Sciences, University of Stirling, Scotland FK9 4LA.

Present address: División Académica de Ciencias Biológicas, Universidad Juárez Autónoma de Tabasco, km 0.5 Carr. Vhs-Cardenas, Villahermosa, Tab. México; jlmart@ cicea.ujat.mx

Received 31-V-2002. Corrected 13-VII-2004. Accepted 19-XI-2004.

\begin{abstract}
In tropical forests with nutrient-rich soil tree's nutrient resorption from senesced leaves has not always been observed to be low. Perhaps this lack of consistence is partly owing to the nutrient resorption methods used. The aim of the study was to analyse $\mathrm{N}$ and $\mathrm{P}$ resorption proficiency from tropical rain forest trees in a nutrientrich soil. It was hypothesised that trees would exhibit low nutrient resorption in a nutrient-rich soil. The soil concentrations of total $\mathrm{N}$ and extractable $\mathrm{P}$, among other physical and chemical characteristics, were analysed in 30 samples in the soil surface $(10 \mathrm{~cm})$ of three undisturbed forest plots at 'Estación de Biología Los Tuxtlas' on the east coast of Mexico (18 $\left.34^{\prime}-18^{\circ} 36^{\prime} \mathrm{N}, 95^{\circ} 04^{\prime}-95^{\circ} 09^{\prime} \mathrm{W}\right)$. N and P resorption proficiency were determined from senescing leaves in 11 dominant tree species. Nitrogen was analysed by microkjeldahl digestion with sulphuric acid and distilled with boric acid, and phosphorus was analysed by digestion with nitric acid and perchloric acid. Soil was rich in total $\mathrm{N}(0.50 \%, \mathrm{n}=30)$ and extractable $\mathrm{P}\left(4.11 \mu \mathrm{g} \mathrm{g}^{-1}, \mathrm{n}=30\right)$. As expected, trees showed incomplete $\mathrm{N}(1.13 \%, \mathrm{n}=11)$ and $\mathrm{P}(0.11 \%, \mathrm{n}=11)$ resorption. With a more accurate method of nutrient resorption assessment, it is possible to prove that a forest community with a nutrient-rich soil can have low levels of N and P resorption. Rev. Biol. Trop. 53(3-4): 353-359. Epub 2005 Oct 3.
\end{abstract}

Key words: Los Tuxtlas, lowland forest, Mexico, resorption proficiency, senescent leaves.

In many lowland tropical forests nutrient limitation for plant growth is a common issue chiefly owing to nutrient-poor soils (Sanchez 1976, Proctor 1992). In tropical and temperate forests nitrogen $(\mathrm{N})$ and phosphorus $(\mathrm{P})$ resorption from senesced leaves may reflect a plant strategy of conservation of a limiting nutrient (Edwards and Grubb 1982, Vitousek and Sanford 1986, Proctor et al. 1989, Scott et al. 1992, Killingbeck 1996, Songwe et al. 1997). The nutrients which are resorbed from the trees during leaf senescence are directly available for further plant growth, which makes a species less dependent on current nutrient uptake. Nutrients which are not resorbed, however, will be circulated through litterfall in the longer term. All of this have important implications for element cycling at the ecosystem level (Aerts 1996).
There is an unresolved discussion whether nutrient resorption is related to soil fertility, or to internal nutrient sinks in plants, or to some combination of these two. Chapin (1980) pointed out that there was insufficient evidence to support any particular relationship between nutrient resorption and soil fertility. There are studies that demonstrate that nutrient resorption efficiency is higher on infertile soils (Boerner 1984, Scott et al. 1992), on fertile soils, and on intermediate fertility soils. Aerts (1996) found that at the intraspecific level, nutrient resorption was not very responsive to increased nutrient availability.

Proctor et al. (1989) and Thompson et al. (1992) had found large interspecific differences and substantial intraspecific variation in freshleaf element concentrations in the tropical forests. Since nutrient concentrations in fresh leaves are highly variable depending on leaf 
position in the canopy and leaf age, there are not confident estimators of nutrient resorption (Grubb 1989). Killingbeck (1996) has proposed resorption proficiency (absolute nutrient concentration values in senesced leaves) to be a more meaningful and objective measure of the degree of true nutrient resorption than the so far used method of resorption efficiency (difference between fresh and senesced leaves nutrient concentrations). Resorption proficiency values are true nutrient concentration values, while resorption efficiency values are relative quotient values. Absolute nutrient concentration values in senesced leaves represent the levels to which nutrients have been reduced and are an estimation of the degree to which realized resorption approaches potential resorption. From an extensive analysis Killingbeck (1996) concluded that concentrations of $0.3 \%$ nitrogen and $0.01 \%$ phosphorus represent the threshold or ultimate potential resorption (maximal withdrawal of nutrients from senescing leaves) in the plant. For the majority of woody perennial species, nutrient resorption can be considered as highly proficient and thus as a nutrient conservation mechanism, if plants have reduced nitrogen and phosphorus in their senesced leaves to concentrations below $0.7 \%$ and $0.05 \%$ respectively. Resorption proficiency avoids the problem of spatial and temporal variation in nutrient concentrations in the fresh leaves of the trees and then is the method considered throughout this paper.

The aim of this paper was to assess nutrient resorption in a tropical rain forest ecosystem with a nutrient-rich soil. It was hypothesised that $\mathrm{N}$ and $\mathrm{P}$ resorption from trees of a mature forest in a $\mathrm{N}$ and $\mathrm{P}$ rich soil, would be low. The methodology to evaluate nutrient resorption at ecosystem level is also discussed throughout.

\section{MATERIALS AND METHODS}

Study site: The study site was located in the undisturbed forest reserve 'Estación de Biología Los Tuxtlas' on the east coast of Mexico (18 34' - 18³6’ N, 9504' - 9509' W), belonging to the Universidad Nacional Autónoma de Mexico (Fig. 1). Los Tuxtlas is the northernmost extension of the lowland evergreen tropical rain-forest formation in the neotropics. Most of the forest reserve lies over basaltic rocks of about 800000 yr old (Nelson and GonzálezCaver 1992). However, soil development and fertility may have been influenced by relatively recent (in 1664 and 1793) volcanic activity with significant quantities of ash and a small volume of lava flows, as well as by climate (Nelson and González-Caver 1992, Friedlaender and Sander 1923 as cited in Martin-Del Pozzo 1997). Soils in the region are classified as well-drained, coarse-textured, vitric Andosols mixed with volcanic ash (Anonymous 1975); however reliable data on their chemistry is still lacking. Mean annual temperature at the forest reserve is $25.1^{\circ} \mathrm{C}$. Mean annual rainfall is $4487 \mathrm{~mm}$. Evaporation at Sontecomapan (c. $10 \mathrm{~km}$ SE from the reserve) measured as the amount ( $\mathrm{mm}$ ) of water evaporated in a sink in 24-h terms, had an annual mean of $1390 \mathrm{~mm}$ (Martínez-Sánchez 2001).

Soils: Three 50 x 50-m plots were placed in the mature forest of the reserve. Total basal areas of the plots were $8.0,8.1$, and $8.8 \mathrm{~m}^{2}$ (Martínez-Sánchez 1999). During May and October 1996 ten soil samples (0 - $10 \mathrm{~cm}$ deep) in each plot were collected for chemical and physical analyses, in a stratified random way with an 8-cm-diameter soil corer. For soil nutrient analysis, the samples were immediately air-dried and passed through a 1.2-mm mesh. Samples were kept in polythene bags at $20^{\circ} \mathrm{C}$ until the laboratory analyses. Soil bulk density was estimated by drying the samples at about $95^{\circ} \mathrm{C}$ in the oven to a constant weight and then weighing to obtain the dry weight per unit volume $\left(\mathrm{g} \mathrm{cm}^{-3}\right)$. Soil analyses were conducted in the Instituto de Geología of the Universidad Nacional Autónoma de México. Analyses were all made in duplicate and checked with international standards. Soil texture was determined by a hydrometrical technique (Bouyoucos 1963) and the soils were not completely dried in order to prevent organic matter loss which is high in 


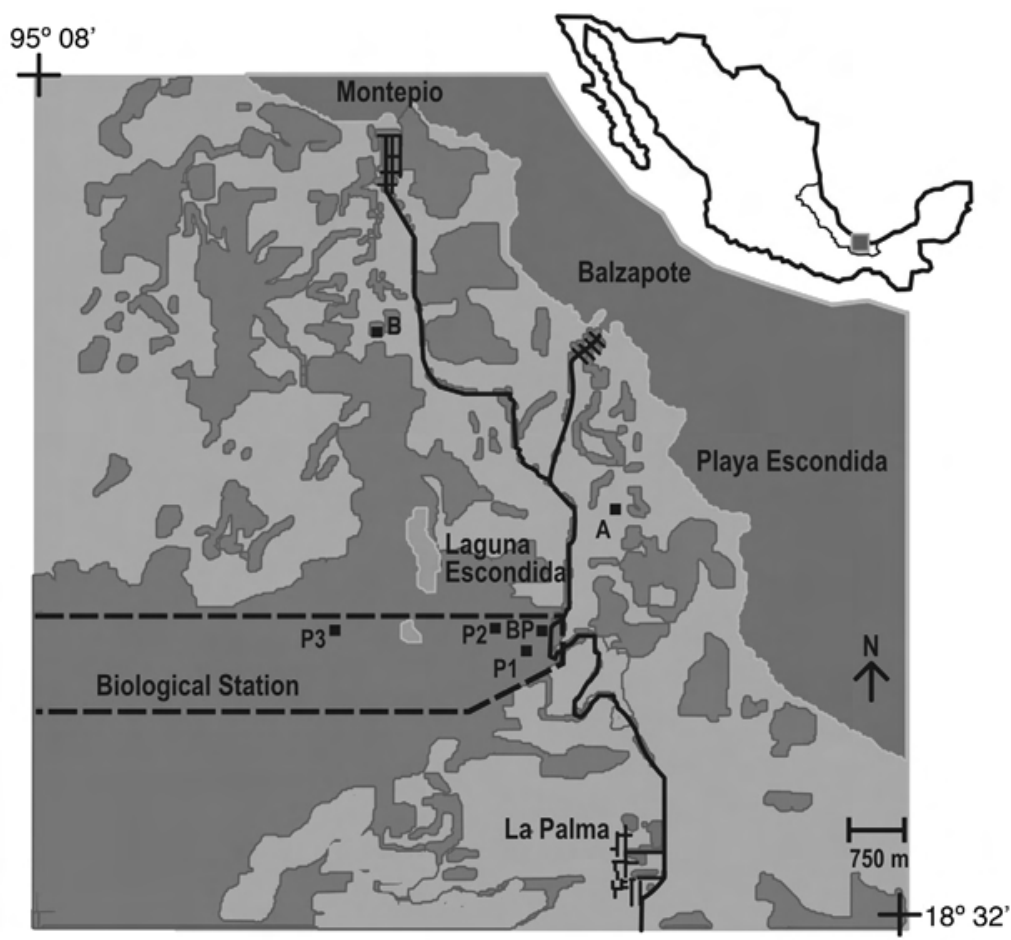

Fig. 1. Location of the study site. Biological Station 'Los Tuxtlas' (LT), forest plots (P1, P2, P3), and the buildings (BP). Dark shading indicates undisturbed forest.

Andosols. For texture classification the United Kingdom system was used. The $\mathrm{pH}$ was determined in $\mathrm{H}_{2} \mathrm{O}(1: 2.5)$ and in a $1 \mathrm{M} \mathrm{KCl}(1: 2.5)$ solution (Schlichting et al. 1995). Total N was analysed by the Kjeldahl method (Black 1965). Phosphorus was extracted by $0.025 \mathrm{M} \mathrm{HCl}$ and $0.03 \mathrm{M} \mathrm{NH}_{4} \mathrm{~F}$ (Black 1965). Exchangeable cations were extracted by $1 \mathrm{M}$ ammonium acetate ( $\mathrm{pH}$ 7). $\mathrm{Ca}^{2+}$ and $\mathrm{Mg}^{2+}$ were determined by atomic absorption spectrophotometry, and $\mathrm{K}^{+}$and $\mathrm{Na}^{+}$by flame photometry in a $\mathrm{CaCl}_{2}$ solution (Bouwer et al. 1952). Exchangeable $\mathrm{Al}^{3+}$ and $\mathrm{H}^{+}$ions were determined by titration with $0.01 \mathrm{M} \mathrm{NaOH}$ in a solution of $1 \mathrm{M} \mathrm{KCl}$ (Van Reenwijk 1992). Cation exchange capacity (CEC) was assessed by the summation of exchangeable cations.

Nutrient resorption assessment: During September 1997 (rainy season) fresh leaves and freshly fallen leaves of 11 tree species were collected for nutrient-element analysis, in about 10 ha of the east side of the reserve including two of the soil plots. The criteria of selection of the species was the proximity and the abundance. The species were dominant in the community such that they accounted for $48 \%$ of the plots basal area and for $44 \%$ of the total leaf litterfall (Martínez-Sánchez 1999). Three trees $(\geq 10 \mathrm{~cm} \mathrm{dbh})$ of each species were randomly selected. Samples of $5 \mathrm{~g}$ of fresh mature shade-leaves were collected from the crown of each tree at a height of 5-15 m; and of $5 \mathrm{~g}$ of freshly $(<3 \mathrm{~d})$ fallen leaves from the ground below each tree. All leaves were dried at c. $40^{\circ} \mathrm{C}$ for $3 \mathrm{~d}$.

Nutrient analyses of leaf material were done in the Laboratorio de Edafología, Colegio de Postgraduados at Montecillos, Mexico. All material was oven-dried at $105^{\circ} \mathrm{C}$. Nitrogen was analysed by microkjeldahl digestion with sulphuric acid and distillation with boric acid (Bremmer 1975, Chapman and Pratt 1979). Phosphorus was analysed by digestion with 
nitric acid and perchloric acid (2:1) for a minimum of $12 \mathrm{~h}$, and determined in $7.5 \mathrm{ml}$ of vanadomolybdenum-phosphorus complex by photometry at $470 \mathrm{~nm}$. Resorption proficiency (nutrient concentration in senesced leaves) was obtained for the purpose of this study, and resorption efficiency (senesced/fresh leaf nutrient concentrations) was calculated for means of comparison with other studies. The variables of nutrient concentrations were analysed for normal distribution by the skewness and kurtosis values and the normal distribution plot with Statgraphics 5.0. Student $t$-test was used to compare two sample means.

\section{RESULTS}

The forest top soil is relatively nutrientrich with a low bulk density $\left(0.75 \mathrm{~g} \mathrm{~cm}^{-3}\right)$, a clay to clay-loam texture, and an almost neutral $\mathrm{pH}_{\mathrm{H} 2 \mathrm{O}}$ (6.9) (Table 1).

$\mathrm{N}$ and $\mathrm{P}$ concentrations values of fresh and senesced leaves (11 species sampled) came from a population with normal distribution (standard skewness and kurtosis < 2).

Mean fresh-leaf nitrogen concentration $(1.79 \%)$ was higher than phosphorus concentration $(0.14 \%, t=9.22, \mathrm{p}=0.0000)$, senesced-leaf nitrogen concentration $(1.13 \%)$ was higher than phosphorus concentration $(0.11 \%, t=8.04$, $\mathrm{p}=0.0000)$, and nitrogen (0.66) and phosphorus
(0.82) resorption efficiency were equal ( $t=$ -1.72, $p=0.101)$. Nutrient concentrations in fresh leaves were higher than in senesced leaves giving values of resorption efficiency lower than one, with exception of $\mathrm{P}$ for Cecropia obtusifolia, Nectandra ambigens and Orthion oblanceolatum. Values of resorption proficiency (senesced leaves) and resorption efficiency varied among species and families without a clear pattern (Table 2). Trichospermum galeottii from the Tilliaceae family appeared as the species with the lowest values of $\mathrm{N}(0.71 \%)$ and $\mathrm{P}$ $(0.04 \%)$ concentrations in senesced leaves and resorption efficiency and Heliocarpus appendiculatus (Tiliaceae also) had the highest $\mathrm{P}(0.23 \%)$ value in senesced leaves.

\section{DISCUSSION}

The proximity to the sea does not seem to influence the relatively high soil $\mathrm{pH}$ at this location (Martínez-Sánchez 1999). Bongers et al. (1988) had previously determined a $\mathrm{pH}_{\mathrm{H}_{2} \mathrm{O}}$ of 6.3 at $15 \mathrm{~cm}$ depth in the same site.

Plants tend to save nutrients from each fallen leaf and reassign to other vital part of the plant, and then perform some degree of nutrient resorption usually giving higher nutrient concentrations in fresh leaves than in senesced leaves. Exceptional cases were the species Cecropia obtusifolia, Nectandra ambigens and

\section{TABLE 1}

\begin{tabular}{|c|c|c|c|c|c|c|c|c|c|}
\hline \multirow[b]{2}{*}{ Mean } & \multirow{2}{*}{$\begin{array}{c}\mathrm{K}^{+} \\
\left(\mathrm{cmol}_{\mathrm{c}} \mathrm{kg}^{-1}\right) \\
0.62\end{array}$} & $\begin{array}{c}\mathrm{Na}^{+} \\
\left(\mathrm{cmol}_{\mathrm{c}} \mathrm{kg}^{-1}\right)\end{array}$ & \multicolumn{2}{|c|}{$\begin{array}{c}\mathrm{Ca}^{2+} \\
\left(\mathrm{cmol}_{\mathrm{c}} \mathrm{kg}^{-1}\right)\end{array}$} & \multicolumn{2}{|c|}{$\begin{array}{c}\mathrm{Mg}^{2+} \\
\left(\mathrm{cmol}_{\mathrm{c}} \mathrm{kg}^{-1}\right)\end{array}$} & \multirow{2}{*}{$\begin{array}{c}\mathrm{Al}^{3+} \\
\left(\mathrm{cmol}_{\mathrm{c}} \mathrm{kg}^{-1}\right) \\
0.14\end{array}$} & \multirow{2}{*}{$\begin{array}{c}\mathrm{H}^{+} \\
\left(\mathrm{cmol}_{\mathrm{c}} \mathrm{kg}^{-1}\right) \\
0.31\end{array}$} & \multirow{2}{*}{$\begin{array}{c}\text { CEC } \\
\left(\mathrm{cmol}_{\mathrm{c}} \mathrm{kg}^{-1}\right) \\
24.4\end{array}$} \\
\hline & & 0.54 & 14 & & & & & & \\
\hline \multirow[t]{2}{*}{ S.D. } & 0.28 & 0.04 & & & & & 0.03 & 0.011 & 4.41 \\
\hline & $\begin{array}{l}\text { Bulk density } \\
\qquad\left(\mathrm{g} \mathrm{cm}^{-3}\right)\end{array}$ & Clay (\%) & Silt (\%) & Sanc & $(\%)$ & $\begin{array}{l}\mathrm{pH}_{\mathrm{H} 20} \\
(1: 2.5)\end{array}$ & $\begin{array}{l}\mathrm{pH}_{\mathrm{KCl}} \\
(1: 2.5)\end{array}$ & Total N (\%) & $\begin{array}{l}\text { P Bray } \\
\left(\mu \mathrm{g} \mathrm{g}^{-1}\right)\end{array}$ \\
\hline Mean & 0.75 & 33.9 & 31.9 & & 0 & 6.92 & 5.54 & 0.50 & 4.11 \\
\hline S.D. & 0.076 & 4.42 & 1.43 & & 2 & 0.096 & 0.23 & 0.084 & 2.91 \\
\hline
\end{tabular}


TABLE 2

Mean nitrogen and phosphorus concentrations (\%) in fresh and senesced leaves (Resorption Proficiency)

\begin{tabular}{|c|c|c|c|c|c|c|c|}
\hline Family & Species & $\begin{array}{c}\text { Fresh } \\
\% \mathrm{~N}\end{array}$ & $\begin{array}{c}\text { leaves } \\
\% \mathrm{P}\end{array}$ & $\begin{array}{c}\text { Senesced } \\
\% \mathrm{~N}\end{array}$ & $\begin{array}{c}\text { leaves } \\
\% \mathrm{P}\end{array}$ & $\begin{array}{c}\text { Resorption } \\
\mathrm{N}\end{array}$ & $\begin{array}{c}\text { efficiency } \\
\text { P }\end{array}$ \\
\hline Anacardiaceae & Spondias radlkoferi Donn. Sm. & 1.25 & 0.13 & 1.04 & 0.09 & 0.89 & 0.70 \\
\hline Cecropiaceae & Cecropia obtusifolia Bertol. & 1.99 & 0.18 & 1.19 & 0.17 & 0.59 & 1.03 \\
\hline Clusiaceae & Rheedia edulis (Seem.) Triana \& Planch. & 1.08 & 0.07 & 0.79 & 0.05 & 0.73 & 0.72 \\
\hline Lauraceae & Nectandra ambigens (S.F. Blake) C.K. Allen. & 1.68 & 0.13 & 1.01 & 0.13 & 0.61 & 1.29 \\
\hline Moraceae & Ficus tecolutensis (Liebm.) Miq. & 1.38 & 0.11 & 0.86 & 0.08 & 0.62 & 0.76 \\
\hline Moraceae & F. yoponensis Desv. & 2.08 & 0.15 & 0.99 & 0.08 & 0.48 & 0.55 \\
\hline Moraceae & Pseudolmedia oxyphyllaria Donn. Sm. & 1.54 & 0.11 & 1.28 & 0.08 & 0.83 & 0.69 \\
\hline Rubiaceae & Faramea occidentalis (L.) A. Rich. & 1.40 & 0.11 & 1.25 & 0.08 & 0.89 & 0.98 \\
\hline Tiliaceae & Heliocarpus appendiculatus Turcz. & 2.26 & 0.29 & 1.03 & 0.23 & 0.46 & 0.79 \\
\hline Tiliaceae & Trichospermum galeottii (Turcz.) Kosterm. & 1.85 & 0.12 & 0.71 & 0.04 & 0.39 & 0.36 \\
\hline \multirow[t]{3}{*}{ Violaceae } & Orthion oblanceolatum Lundell. & 3.18 & 0.17 & 2.26 & 0.17 & 0.72 & 1.19 \\
\hline & Mean & 1.79 & 0.143 & 1.13 & 0.109 & 0.66 & 0.82 \\
\hline & SD & 0.59 & 0.057 & 0.42 & 0.058 & 0.17 & 0.27 \\
\hline
\end{tabular}

Resorption efficiency $=$ senesced $/$ fresh leaves nutrient concentrations.

The highest and the lowest values are shown in bold $(n=3)$.

Orthion oblanceolatum which had resorption efficiency values for phosphorus above one indicating an unusual lost of this element through their leaves or lack of resorption.

A high variation in nutrient resorption efficiency and proficiency was found among the species and families analysed from this forest community. The Tiliaceae family e.g. had the species with the highest (H. appendiculatus, 0.23 ) and lowest (T. galeottii, 0.04) P resorption. Singh (1969) had found much variation in leaf litterfall nutrient concentrations of different forest species and Scott et al. (1992) found large inter-specific variations also.

The mean values of nutrient concentrations in senesced leaves in their lowest, intermediate and highest ranges at this location were all higher compared to those reported by Killingbeck (1996) from 77 tree species worldwide. Lowest values $(0.71 \% \mathrm{~N}$ and $0.04 \%$ P) were above Killingbeck's lowest values $(0.26 \% \mathrm{~N}$ and $0.01 \% \mathrm{P})$; overall mean values $(1.13 \% \mathrm{~N}$ and $0.11 \% \mathrm{P})$, above $0.87 \% \mathrm{~N}$ and $0.06 \% \mathrm{P}$; and highest values $(2.26 \% \mathrm{~N}$, Orthion oblanceolatum; $0.23 \%$ P, Heliocarpus appendiculatus) above $1.90 \% \mathrm{~N}$ and $0.21 \% \mathrm{P}$. This indicates that Los Tuxtlas forest appeared in the low range of nutrient resorption from many forest communities around the world.

Killingbeck (1996) proposed thresholds for $\mathrm{N}$ and $\mathrm{P}$ resorption proficiency in senesced leaves of woody species. He proposed that leaves might approach complete, intermediate, and incomplete nitrogen resorption, when concentration $<0.7 \%, 0.7-1.0 \%$, and $>1.0 \%$, respectively. For phosphorus in evergreen species he proposed $<0.04 \%, 0.04-0.05 \%$, and $>$ $0.05 \%$, for complete, intermediate, and incomplete resorption, respectively. Compared to these values, most species from this study had incomplete, and only few intermediate, $\mathrm{N}$ and $\mathrm{P}$ resorption (Table 2). Based on this index, no single species neither part of the community (based on 11 dominant tree species that represents $48 \%$ of the total basal area and $44 \%$ of the total leaflitter productivity), showed a strong nutrient conservation mechanism at Los Tuxtlas.

Concentrations of total $\mathrm{N}$ in the soil from a range of lowland rain forests around the world were 0.02-1.0\% (Proctor 1983). Extractable $\mathrm{P}$ in one alluvial soil and one entisol in Costa Rica were 3.6 and $2.2 \mu \mathrm{g} \mathrm{g}^{-1}$ (Werner 1984, 
Grieve et al. 1990). Compared to these values, soil concentrations of total $\mathrm{N}(0.50 \%)$ and extractable $\mathrm{P}\left(4.11 \mu \mathrm{g} \mathrm{g}^{-1}\right)$ at Los Tuxtlas appeared as high.

Nutrient resorption has not been experimentally demonstrated to depend directly on soil nutrients availability. From many experiments analysed at intraspecific level, only in $32 \%$ of the cases $\mathrm{N}$ resorption decreased in response to increased $\mathrm{N}$ availability, whereas in $63 \%$ of the cases no response was observed. For $\mathrm{P}$, only in $35 \%$ of the cases resorption decreased upon enhanced nutrient supply, while in 57\% there was no response (Aerts 1996).

Phosphorous has often been found with greater percentages of resorption than N (Attiwill 1968, Songwe et al. 1997) partly indicating less availability of this key element in the ecosystems. In an oligotrophic Amazonian rain forest, leaf $\mathrm{P}$ resorption $(62 \%)$ was greater than $\mathrm{N}$ resorption $(43 \%)$ in crop, weed and tree species (Reich et al. 1995). At Los Tuxtlas, N and $\mathrm{P}$ were resorbed in equal manner though both approached incomplete nutrient resorption, perhaps owing to the nutrient rich soil condition.

From these high nutrient concentrations in the senesced leaves and high nutrient concentrations in the soil, it can be concluded that the hypothesis was confirmed for this forest having low nutrient resorption in a nutrientrich soil. The study demonstrates that with a more accurate method of nutrient resorption assessment it is possible to prove that a forest community with nutrient-rich soil can have low $\mathrm{N}$ and $\mathrm{P}$ resorption.

\section{ACKNOWLEDGMENTS}

I am grateful to John Proctor, Steven Oberbauer and three anonymous reviewers for their valuable criticism. Thanks to Silvia Sánchez B. for the soil analyses. This study was part of my Ph.D. thesis supported by scholarships from CONACYT and SEMARNAP in México.

\section{RESUMEN}

En las selvas tropicales con suelos fértiles se ha observado que la reabsorción de nutrientes de los arboles de las hojas seniles no siempre es baja. Esta falta de consistencia en el resultado es talvez debida en parte a la metodología de reabsorción de nutrientes utilizada. El objetivo de este estudio fue analizar la reabsorción final de $\mathrm{N}$ y $\mathrm{P}$ de arboles de la selva húmeda tropical en un suelo rico en nutrientes. La hipótesis planteada fue que en un suelo rico en nutrientes los arboles presentarían una baja reabsorción final de nutrientes. En 30 muestras del suelo superficial $(10 \mathrm{~cm})$ de tres sitios de la selva no perturbada, se analizó entre otras características físicas y químicas, la concentración de $\mathrm{N}$ total y $\mathrm{P}$ extraíble. A través de la concentración de $\mathrm{N}$ y $\mathrm{P}$ en hojas seniles, se determinó la reabsorción real de 11 especies dominantes de arboles de esta selva. El N se analizó por digestión microkjeldahl con ácido sulfúrico y destilación con ácido bórico, y el $\mathrm{P}$ se analizó por digestión con ácido nítrico y destilación con perclórico. El suelo fue rico en $\mathrm{N}$ total $(0.50 \%, \mathrm{n}=30) \mathrm{y}$ P extraíble $\left(4.11 \mu \mathrm{g} \mathrm{g}^{-1}, \mathrm{n}=30\right)$. Tal como se esperaba, los arboles mostraron una reabsorción incompleta para el $\mathrm{N}$ $(1.13 \%, \mathrm{n}=11)$ y $\mathrm{P}(0.11 \%, \mathrm{n}=11)$.

Palabras clave: Hojas seniles, Los Tuxtlas, México, reabsorción real, selva húmeda tropical.

\section{REFERENCES}

Anonymous. 1975. Soil maps of the world. Vol. III. Mexico and Central America. FAO/UNESCO, Paris.

Aerts, R. 1996. Nutrient resorption from senescing leaves of perennials: are there general patterns? J. Ecol. 84: 597-608.

Attiwill, P.M. 1968. The loss of elements from decomposing litter. Ecology 49: 142-145.

Black, C.A. 1965. Methods of soil chemical analysis and microbiological properties. Agronomy No. 9. American Society of Agronomy, Madison.

Boerner, R.E.J. 1984. Foliar nutrient dynamics and nutrient use efficiency of four deciduous tree species in relation to site fertility. J. Appl. Ecol. 21: 1029-1040.

Bongers, F., J. Popma, J. Meave del Castillo \& J. Carabias. 1988. Structure and floristic composition of the lowland rain forest of Los Tuxtlas, Mexico. Vegetatio. 74: $55-80$. 
Bouwer, C.A., R.F. Reitemeier \& R. Fireman. 1952. Exchangeable cation analysis of saline and alkali soils. Soil Sci. 73: 251-261.

Boyoucous, G.J. 1963. Directions for making mechanical analyses of soil by hydrometer method. Soil Sci. 42: 25-30.

Bremmer, J.M. 1975. Total nitrogen, p. 1149-1178. In C.A. Black (ed.). Methods of soil analysis, Part 2. Agronomy. American Society of Agronomy, Madison.

Chapin, F.S. 1980. The mineral nutrition of wild plants. Annu. Rev. Ecol. Syst. 11: 233-260.

Chapman, H.D. \& P. F. Pratt. 1979. Métodos de análisis para suelos, plantas y agua. Ed. Trillas, México. 195 pp.

Edwards, P.J. \& P.S. Grubb. 1982. Studies of mineral cycling in a montane rain forest in New Guinea. IV. Soil characteristics and the division of mineral elements between the vegetation and soil. J. Ecol. 70: 649-666.

Grieve, I.C., J. Proctor \& S.A. Cousins. 1990. Soil variation with altitude on Volcan Barva, Costa Rica. Catena. 17: 525-534.

Grubb, P.J. 1989. The role of mineral nutrients in the tropics: a plant ecologist's view, p. 417-439. In J. Proctor (ed.). Mineral Nutrients in Tropical Forest and Savanna Ecosystems, BES Special publ. No.9. Blackwell, Oxford.

Killingbeck, K.T. 1996. Nutrients in senesced leaves: keys to the search for potential resorption and resorption proficiency. Ecology 77: 1716-1727.

Martin del pozzo, A.L. 1997. Geología, p. 25-31. In E. González, R. Dirzo \& R.C. Vogt (eds.). Historia natural de Los Tuxtlas. Universidad Nacional Autónoma de Mexico. CONABIO, México.

Martínez-Sánchez, J.L. 1999. Nutrient dynamics in the tropical rain forest and pastures of Los Tuxtlas, México. Ph.D. thesis. University of Stirling, UK. $145 \mathrm{p}$.

Martínez-Sánchez, J.L. 2001. Leaf litterfall composition in a tropical rain forest in México. GeoEcoTrop. 25: $29-44$.

Nelson, S.A. \& E. González-Caver. 1992. Geology and $\mathrm{K}$-Ar dating of the Tuxtla volcanic field, Veracruz, México. Bull. Vulcan. 55: 85-96.
Proctor, J. 1992. Soils and mineral nutrients: What do we know, and what do we need to know, for wise rain forest management, p. 27-35. In F. Miller (ed.). The Wise Management of Tropical Forests. Oxford Forestry Institute, Oxford.

Proctor, J., J.M. Anderson, P. Chai \& H.W. Vallack. 1983. Ecological studies in four contrasting lowland rain forest in Gunung Mulu National Park, Sarawak. I. Forest environment, structure and floristics. J. Ecol. 71: 237-260.

Proctor, J., C. Phillipps, G.K. Duff, A. Heaney \& F.M. Robertson. 1989. Ecological studies on Gunung Silam, a small ultrabasic mountain in Sabah, Malaysia. II. Some forest processes. J. Ecol. 77: 317-331.

Reich, P.B., D.S. Ellsworth \& C. Uhl. 1995. Leaf carbon and nutrient assimilation and conservation in species of differing successional status in an oligotrophic Amazonian forest. Funct. Ecol. 9: 63-76.

Sánchez, P.A. 1976. Properties and Management of Soils in the Tropics. John Wiley \& Sons. New York. 618 p.

Schlichting, E., H.P. Blume \& K. Staler. 1995. Bodenkundliches Praktikum. Pareys Studientexte 81, Blackwell Wissenchafts-Verlag, Berlin. 132 p.

Scott, D.A., J. Proctor \& J. Thompson. 1992. Ecological studies on a lowland evergreen rain forest on Maracá Island, Roraima, Brazil. II. Litter and nutrient cycling. J. Ecol. 80: 705-717.

Singh, K.P. 1969. Nutrient concentration in leaf litter of 10 important tree species of the deciduous forest at Varanasi. Trop. Ecol. 10: 83-95.

Songwe, F.E., F.E. Fasehun \& D.U.U. Okali. 1997. Leaf nutrient dynamics of two tree species and litter nutrient content in Southern Bakundu Forest Reserve, Cameroon. J. Trop. Ecol. 13: 1-15.

Thompson, J., J. Proctor, V. Viana, W. Milliken, J.A. Ratter \& D. A. Scott. 1992. Ecological studies on a lowland evergreen rain forest on Maraca Island, Roraima, Brazil. I. Physical environment, forest structure and leaf chemistry. J. Ecol. 80: 689-703.

Van Reenwijk, L.P. 1992. Procedures for soil analysis. ISRIC, Wageningen.

Vitousek, P.M. \& R.L. Sanford. 1986. Nutrient cycling in moist forests. Annu. Rev. Ecol. Syst. 17: 137-167.

Werner, P. 1984. Changes in soil properties during tropical wet forest succession in Costa Rica. Biotropica 16: 43-50. 
